\begin{tabular}{|c|c|}
\hline $\begin{array}{r}\text { ARTICLES } \\
\text { ARTICULOS }\end{array}$ & $\begin{array}{l}\text { THE EXTENDED SPACE } \\
\text { OF PUBLIC OPINION IN } \\
\text { THE CONTEXT OF MULTI- } \\
\text { PLATFORM JOURNALISM: } \\
\text { from speakers to discursive actors' }\end{array}$ \\
\hline $\begin{array}{r}\text { Copyright @ } 2015 \\
\text { SBPPjor / Associacăo } \\
\text { Brasileira de } \\
\text { Pesquisadores em } \\
\text { Jornalismo }\end{array}$ & $\begin{array}{l}\text { KATI ELIANA CAETANO } \\
\text { Universidade Tuiuti do Paraná, Brazil }\end{array}$ \\
\hline
\end{tabular}

\begin{abstract}
This paper has as its starting point the traditional condition of the public opinion, especially in its form of existence in the mass communication society, when assuming the role of legitimizer of protagonists' speeches in the political scene - government and media. It aims to show its character of built object under the set of discursive conventions, and the modifications that it goes through in the context of current journalism, presenting itself as a multitude of voices visible in the information circulation spaces. The analysis of qualitative nature focuses on opinions on the conflict Israel / Palestine, obtained from reader comments and captured through search applications on the Internet based on the tag related to the fact in the period of June-September 2014 . Among these changes, we integrate the need to resize its concept, the comprehension of the challenge that such aspect represents to news organizations and the review of their own formal elaborations that sustain the journalistic discourse.
\end{abstract}

Key words: Public opinion. Information flows. Discursive actors. Communication in act. Israel/Palestine conflict.

\title{
O ESPAÇO DILATADO DA OPINIÃO PÚBLICA NO CONTEXTO DO JORNALISMO EM MULTIPLAS PLATAFORMAS: de seus porta-vozes aos atores discursivos
}

RESUMO - A proposta tem como ponto de partida a condição tradicional da opinião pública, sobretudo em sua forma de existência na sociedade de comunicação massiva, quando assume o papel de legitimadora das falas de protagonistas da cena política - governantes e mídias. Visa a mostrar, a partir desse quadro, seu caráter de objeto construído no âmbito de um conjunto de convenções discursivas, e as modificações que sofre no contexto do jornalismo atual, apresentando-se como uma multitude de vozes tornadas visíveis nos espaços de circulação da informação. A análise, de cunho qualitativo, está centrada em opiniões sobre o conflito Israel/ Palestina, obtidas a partir dos comentários de leitores e capturadas por meio de aplicativos de busca na internet com base na tag referente ao fato no período de junho a setembro de 2014. Entre tais mudanças, integram-se a necessidade de redimensionamento de seu conceito, a compreensão do desafio que tal aspecto representa às organizações jornalísticas e o reexame das próprias elaborações formais que sustentam o discurso jornalístico.

Palavras-chave: Opinião pública. Fluxos informacionais. Atores discursivos. Comunicação em ato. Conflito Israel/Palestina. 


\title{
EL ESPACIO DILATADO DE LA OPINIÓN PÚBLICA EN EL CONTEXTO DEL PERIODISMO EN MULTIPLATAFORMAS: de sus portavoces a los actores discursivos
}

\begin{abstract}
RESUMEN - La propuesta toma como punto de partida la condición tradicional de la opinión pública, sobre todo en su forma de existencia en la sociedad de la comunicación de masas, cuando asume el papel de razonar los discursos protagonistas de la escena política - gobierno y los medios. Tiene como objetivo exponer, a partir de ese marco, su objeto de carácter construido bajo un conjunto de convenciones discursivas, y las transformaciones que ocurren en el contexto del periodismo actual, presentándose como una multitud de voces tornadas visibles en los espacios de circulación de la información. El análisis, de carácter cualitativo, se centra en las opiniones sobre el conflicto Israel/ Palestina, obtenidas a partir de comentarios de los lectores y capturados a través de aplicaciones de búsqueda en Internet basadas en la tag "opinión pública" en el período junio-septiembre 2014. Así, son discutidas la necesidad de redimensionamiento de su concepto, la comprensión del desafío que este aspecto representa a las organizaciones de noticias y la revisión de las elaboraciones formales que apoyan el discurso periodístico. Palabras clave: Opinión pública. Flujos de información. Actores discursivos. Comunicación en acto. Conflicto Israel/Palestina.
\end{abstract}

\section{SUBJECTS-REFERENCES: BETWEEN REPRESENTATIONS AND MEDIATIONS}

The ways in which the question of public opinion has been configured in are theoretically closely linked to the ways in which political protagonists and the media create them. Their concepts, therefore, represent forms of theorizing the roles endowed in them according to the interests and needs of different groups. They are defined as a standardized expression of consensual or collective ways of thinking, an instance of controversies and contradictions which are fundamental to democratic processes (HABERMAS, 1994), and expressions conditioned by political directions or media agenda. In all these meanings, the concepts of public opinion formulated by various trains of thought have a common tensioning, one that drives and validates actions and positions, whether according to public powers or to journalism (LANDOWSKI, 1992). Obviously, in certain discourses this object being spoken of -"public opinion"- could also be the subject who is speaking. In the first case, its discursive component is clear. It is more than a reference to empirical actors, whether it is validating a political voice or a majority segment within the social context which the press mediates together with the State. In the first incidence, the adage is that actions are justified by the wishes or the 
needs expressed in public opinion, and, in this case, the government actions do nothing more than answer popular demand. In the second incidence, public opinion demands, deserves or requires attention which is impossible for politics to meet yet is supported in media. It is best put as an outward ability to speak for the public: "with the dual function of communicator, returning to the 'scene' in order to question the political class one moment and returning to the 'stands' in order to make enquiries, if necessary, to the "public the next" (LANDOWSKI, p. 26). As Landowski analyses, a "silence of the public" due to the emergence of the "discourse of opinion" is recognized here, meaning, within the framework of a dramatization of social communication"(p. 26). Voices eventually emerge from this shuttle of delegations in more concrete moves to plead their interests and call for changes. In other words, when referring to third person (or no person) speech, this distinct voice can take place in the first-person collective, that is, it can effectively be the subject of its own discourse. In the framework of linguistic studies, we must take into account that the theories of the constitution of subjectivity, developed by Émile Benveniste, clarified that unlike the classification of most of the grammar in Romance languages, the discourse subjects are only comprised of the positions I-you/us, leaving out the position of third person as it is the one who is spoken of and not the one who does the speaking (he/she). The author refers to Arab grammarians as a starting point for his analysis for whom the first person is the one who speaks, the second person is the one we speak to, yet the third person is absent. (1976, p. 250)

His analysis is of special interest in addressing the reconfiguration of subjectivity in contemporary times because it articulates around a facilitating cultural framework of participatory culture supported by current technologies.

The concept of public opinion is obviously not new; its origin is in the story of the cultural background of collective management, consolidated with the creation of the public sphere and is becoming increasingly more abstract in view of the solidification of the State, especially when this presumably synthesizes the role of liberal bias. In Cândido Teobaldo de Souza Andrade's classic text from 1964 Myth and reality of public opinion, "the term 'public opinion' (meaning popular participation in issues of public interest) really came about in the middle of the 18th century from Jean Jacques Rousseau, author of the Social Contract, when he wrote that the will of the people is 
the only source of sovereignty and laws." (p. 2). In the early 20th century, Walter Lippmann's work public opinion would bring a critical view to the concepts of public opinion, mainly within the framework of stereotype standards (LIPPMANN, 2010).

In this context, the expression "public opinion" is increasingly evoked in the sense of a uniform mass to which it grants specific spaces in the media for expression in the form of letters, planned debates, articles, and expression of opinions in statistical research. It is in this process (not only historical) that its definition is outlined both more vaguely and more inaccurately insofar as the semantic values of "opinion" and "public" acquire different nuances. How is an opinion expressed? Is it through election campaigns or a letter supporting or questioning an idea/initiative? Similarly, how does the "public" express itself? By adding a micro-collective, interpreted as something that influences the vast majority, and is then interpreted as the call of a nation? ${ }^{[2]}$ By opposing everything private? Now, we know that public and private are both made up of a collective and an individual, giving new shades to its content. The collective public would bring this idea of a mass (although not homogenous), but the individual public has something of a small committee that speaks and acts on behalf of a larger audience. In short, the possible definitions of public opinion are both ambiguous, in addition to revealing certain shortcomings in their own denominations. Opinionating is about reacting to something, a passive-active order which gives back what it suggests. Not in terms of production, but reaction, even when that reaction reconfigures a state of things through its own mobility. The term public convenes a private sphere, the one that manages individuals as social beings in interaction. In this context, individuals interact through dialogue and interlocutions, in the form of words. As you can see, the abundance of conceptual problems that mobilizes the "public opinion" category intensifies the polemics of discussions about its uses, together with the varied applications of the expression, leading to the theory that the construction of "public opinion" is a component of speech,

Whether we stigmatize the excessive consideration of "opinion" or downgrade it, it puts us in a demonstrative perspective that grants the status of social actor with empirical existence which is not an object constructed as part of a set of narrative and discursive conventions. Far from demystifying, criticism is subjected to problems that make an incriminated "state of affairs" possible and does not touch the principles or phenomena that it denounces. (LANDOWSKI, 1992, p. 42-43) 


\section{AUDIENCE RECONFIGURATION AND NEW FORMS OF SUBJECTIVITY}

Even if such a concept is touted as traditional, confusing and controversial, it is necessary to consider that its invocation is not out of context in contemporary society. Simply search sites with the tag "public opinion", the events on these sites were triggered by Google Alerts during the months of June to October 2014, to see numerous examples that approve of whether to convene or react against this force ${ }^{[3]}$. It appears multiple times and personifies opinion polls, aimed at giving credibility to the data through encrypted objectifications in statistical components.

However, it is clear that the model for information streams in contemporary society, in a digital culture, change this picture to the extent that it enables for collaborative exchanges, production of individual and parallel content over mainstream media, discussions, comments, corrections, and unveilings. This scenario sets up a remission scheme which merges opinions and audiences from the mass media with the more recent media and with the debates or discussions on social networks. Merging does not mean combining. Each media has its own space in the form of assignments and references. They create a logic of media self-reference devoted both to analyzing facts and the forms of opinion and expression of the interlocutors. Indeed, references that disqualify an interlocutor from a discussion are common, whether by the presumably poor reasoning adopted or by the way it is expressed. Such detractions involve a sequence of shifts that divert the subject in focus when it doesn't lessen the number of participants. "Reader's Panel" comments posted on 07/30/2014 for the online version of the Folha de São Paulo illustrate an example of this: "When someone calls themselves a teacher or historian, as the reader does/.../ it looks so bad, so unfocused, Ricardo Melo's article proves to us that our education is really bad "[4].

Television news refers to digital news sites or opens space for online participation (even if in most cases it is laughable). The mainstream press is cited in online opinions as both a source of authority or as a discourse to be either unveiled or deconstructed. Whether following these mediating instances of collective opinion or addressing them, there are still various forms of challenging them or tricking them. Approving or opposing the provision of the facts in mass media is common. In the first case, its status is one of authority 
by referencing discourse (the idea that "it was on the news" makes it true, is a common example); the second one is as a target of criticism, disputes and unveilings. The challenge to its alleged objectivity/ neutrality is through the revelation of their mistakes, through the demand or questioning of its discourses and sources (see the episode with the FSP and the newspaper O Globo about an interview with Felipe Scolari's double, the coach of the Brazilian team in the World Cup 2014); and strategies for "cheating" appear in false advertisements, in rumors at the last minute with accurate data which forced many outlets to reproduce information so as order to not appear out-of-date, and then consequently have to adjust their content. These are found most often in forms of discrediting news journalism (one example being hashtag: "shut your mouth, Galvão!"[5]), such as websites or social networks that specialize in spreading false news.

In this sense, more than establishing the common citizen as someone who also produces information or participates in its production process, the contemporary society favors, thanks mainly to platforms available, the emergence of a complicated game of voices that make up social relations, more clearly accessible in their own internal media structure. It does not only deal with cards, signed material, special panels our other work destined towards giving the reader a voice. New forms of participation delve into the media space, sometimes without even having a specific rhetoric of journalistic discourse of solid argumentative complexion, explanation of sources and proof; but on the contrary, engender it as the prosaic place for everyday conversations. In fact, although it maintains the idea of a public opinion in conventional molds, the sociocultural environment favors a productive interagent. We prefer to use the term interagent instead of active/passive because the participations are not always active in terms of effective production of information, many of the insertions are duplicates, brief comments, "liked" and shared summaries, furthermore, there is no way to disregard the fact that the spaces for such demonstrations also dilated, out of necessity for traditional media to the new logic of online discussions. In blogs, twitters, and other forms of symbolic exchanges, more elaborate conceptual texts merge with opinions of passion, mere sanctions or disagreements, and are not always formulated in the same tone of the debate but assure them of their spaces.

Technological conditions ensure this handling seeing as they enable access and insertion in the informational circuit like never seen 
before. If, technically speaking, the environment favors controversies considered ideal by various authors towards exercising democracy (MAGNONI, 2012, p. 38-53), then we know that the spaces are not always liberated, just as we know they are not guaranteed to all the conditions of appropriation of more sophisticated devices that allow the full use of their potential such as effective speed in interactional exchanges, range of flows, multimedia and multiplatform.

Multi-platforms of transit information within the framework of changes processed for these new environments are worth highlighting. They are operated by mobile devices with web access, almost real-time interaction, and multimedia resources. In the specific case of journalism, these conditions presuppose faster flows of information from any access point, with combined production and reception, actioned by subjects also in flux, with international implications important to this study.

\subsection{INFORMATIONAL FLOWS, SUBJECTS IN FLUX}

This aspect affects the productive and distributive logic of contemporary journalism in that it dilates the transition space of information, replicates the number of discursive actors, the number of replica discursive actors invested in the role of producers and mediators, and also registers the act of reception in a mobile space of subject displacement. Being in flux in the flow of information suggests more hasty participation; many times originating in the heat of the moment, and that is why there are tendencies to withdraw derivatives and emotional aspects from a round of discussions. Flux is not seen here as just the simple idea of a movement, but a rhythm attached to precipitated and thoughtless actions.

\footnotetext{
It is necessary nowadays to give the decisive role to movement both in the forms of understanding and feeling and in the thought processes. The self and the very idea of self, its conception as a synthesis of place and condition are what are really being questioned. The fact of thinking tends to lose itself in the flow of feelings. It is difficult to exercise thought, and even impossible when there is no duration, depth, or when the limits and references become tenuous, when there are no moments to stop or pause. Is it possible to substitute a self with no limits when exercising sensibility or thought? (HAROCHE, 2008, p. 219)
}

Following opinions expressed in relation to the current Israel / Palestine conflict in the Gaza Strip, in different news sites and blogs 
allows for measuring recurring examples on it. While materials, articles and editorials expose the world's outrage towards the consequences of this war, many readers posted argumentative and sentimental comments on the UOL site (and other social networking sites) between July and August 2014 about the fact that since Israel had been attacked by Hamas first, then Israel had the right to retaliate. According to Palestine, the historical question of who occupied the territory first was what justified the onslaught ${ }^{[6]}$. In other words, they stated the justification for war and only discussed who the one to first initiate it was. Some readers' reactions to the video posted by blogger Bia Willcox ${ }^{[7]}$, of $O$ dia online, containing interviews with passersby from different nationalities who were out front of the Blue Mosque in Istanbul while there was a campaign going on against the conflict in Gaza, reveals some of these behaviors that supported values of intolerance and confrontation. The passersby in the video answered the question "Whose side are you on, Israel or Palestine?" and expressed their positions in a reasonable and argumentative way based on claims normally contrary to the effect of the war. Reaction on the posts to the story in the paper varied between support for Willcox's initiative and others who used formal resources such as capital letters, exclamation points, and cursing to support the increase of violent measures:

\begin{abstract}
(Comment 1)
ISRAEL MUST PASS THE RULER ... LIKE THEY DID WITH EGYPT THE SUEZ CANAL - AND WITH LEBANON WHEN THEY DARED TO BLAST THE JEWISH PEOPLE! SHOOT BACK SO THESE HAMAS WAKE UP!!! THEY ARE BRAVE WITH WORLD SUPPORT OF LEFTWINGERS!!!" Like. Reply. 20:34 August 17, 2014"
\end{abstract}

(Comment 2)

RICHT TO SHIT, ALWAYS SPREADING HATRED IN THE WORLD. TAUGHT THEIR CHILDREN TO HATE AND PRACTICE IT.

Obviously, a video report of a little more than three minutes that focuses on different opinions of passersby is not the most in-depth way to address the issue. Participation such as this, and others that summarize the conflict in ten items or five answers ${ }^{[8]}$ are a long way from establishing a proper democratic debate or advocating a certain position on any issue. On the contrary, they create expectations out of superficial responses at the same time that they signal logic of accessions and controversies that pulverize legitimate, conventional points for the emanation of knowledge. 
One of the compensations for the lack of data on a public debate on cyberspace is the remission of hypertexts and hyperlinks, including multimedia sources ${ }^{[9]}$ of audio, image, audio visual, printed material and computer graphics that give greater credibility to someone's words who work in the field of certain uninteresting posts, such as authority sources traditionally given to written texts. Speaking and writing contaminate like this, but in a singular way, because they decentralize the dominance of one of the registers which handle the more adequate mechanisms of persuasion and convincing of its configuration. Informal tones dominate conversations while deviating from the norm( even by those who dominate it quite well), and in the written text cult uses of the language are privileged, in the extended "conversation" established in cyberspace on network communication, both occupy a privileged space, operating in discursive, media and platform convergence. Far from being a mere sociolinguistic phenomenon, this datum justifies the reach of the new context in relation to the collective opinion previously originating from digital technology, to give visibility to an uncountable number of voices which are not intimidated neither in the face of privileged political positions, in a written sense, nor in the domain of linguistic restrictions (which are also, in fact, political content). In summary, the subjects responsible by producing information reconfigure themselves; the condition in which the enunciated acts occur and the temporal marks of participation in the opinionated circuits, marked by the acceleration or deceleration of the subjects entering in communicational processes; just like their processes of perception and knowledge.

\subsection{NEW ARRANGEMENTS FOR CONDUCTING DEBATES}

Restructuring the technological infrastructure, reconfiguring audiences that have the potential to just hear or follow information, the access to data on the web in multiplatform and consequently inserting them in debate circles, and the linguistic freedom coming from a less-controlled merging of written and oral registers requires attention for strategies of forwarding opinions.

Several studies on pragmatics and semantics (DUCROT, 1983; 1985, and 1987), on conversational linguistics (MARCUSCHI, 2000; $\mathrm{KOCH}, 1992$ ), on the interactionism based on acts of speech (AUSTIN, 1991), on analyses of narratives and discursive exchanges on social 
networks (RECUERO, 2009), on studies of analysis of media discourse (CHARAUDEAU, 2006; MAINGUENEAU, 2005) and on applications of these chains in studies and theories from Norman Fairclough (2008), among others, have discussed the ways in which expressions, markers and argumentative operators used in communication can change the course of a discussion by accentuating, changing, devaluing, or revaluing the topics of dialogue ${ }^{[10]}$. Conceiving the structure outlined by network communication in conversational terms, albeit with singularity on top, one can see the relevance of these studies when analyzing current internet productions. This is not only to identify clusters of structuring themes which form (or conform) networks of followers; or to search for the most-followed, discussed or liked topics in a blog, website, or twitter, but to realize that even under the conditions of a more prosaic discourse, with less reflection density, resources of conversational order are possible and present strong conditions when exchanging opinions. It is in this sense that we also see the reconfiguration of audiences which is more flexible and extended through the diversity of platforms in which they could act, and of the subjects, mobilized in the flux and in flux as well as effective in their own political and linguistic domain.

Such processes, more spontaneous and governed by the pace of the discussions, also require strategies, even if modulated at random and in situation. It is the procedures of ordinary conversational practices, with the difference that in these instances, various orders of adjustments to informative circuit are required that shape our knowledge of the socio-cultural movement. On this note, the study on discourses and social change by Norman Fairclough deserves attention, in particular, the forms of international control including, among others, the control of topics and agendas [11]. He goes on to explain:

The aim here is to describe the organizational properties of interactions, which regular functioning and control of interactions depend on. An important question is who controls the interactions and to what level: to what extent is control negotiated as a business venture undertaken by the participants, and to what extent is it asymmetrically exercised by a participant? /.../ Which exchange structure is at work? /.../How are the schedules presented and by whom? How are they policed, and by whom? Does a participant evaluate the expressions of others? To what extent do participants formulate the interaction? What functions do the formulations have and which participants formulate them?" (FAIRCLOUGH, 2008, p. 286) 
Once expanded, the issue of opinion breaks the expectations crystallized in "public opinion", which provides preliminary definitions, theoretical positions marked by lines of thought, and rescues its most literal sense: a public opinion exercised in spaces of free expression. This audience is also not standardized on a common belief; they correspond before to a diverse set of associations established around themes, which break off into sub-themes and derived topics, emerging from the course of interactions, expressed in different languages, migrating from journalistic conversation ${ }^{[12]}$, and founded in multimedia and multi-discourse remissions used as ways to create belief and ultimately as effects of feeling the truth. In this guided communicational design, there are moments of heavy concentration of interest around certain themes, thanks to the scale and intensity of their emotional impact and concrete repercussions on material life. In these cases, the traditional stamp of actual journalistic discourses can regain control of the debates, opening up spaces for interlocution, urging participation to express points of view and, above all, systematizing the controversial game of opinions through headings like "share your opinion" or "learn more".

More than instances of mediation between the public and the different forms of power, it seems to us that the current context basically favors journalism used to the concept of associated societies of Bruno Latour (2012), when the sets of opinions add to a controversial game, from a political, linguistic, cultural and spatial point of view within which the subjects can be drifting conversational circuits. Within this framework of polemic relations, the constituted micro-powers are forged in relation to the talks traditionally centered on the journalist sometimes in the form of constructions of speaking when face-to-face. A noteworthy example is the post in contrast to the previously mentioned article from Diogo Bercito, from the news blog "Very Eastern", which makes use of implausible means to try to stop the blogger when the more "objective" sources of arguments appear to be exhausted. In his text which aims to further discussions on the conflict outside the parameters of Manichaeism ${ }^{[13]}$, Diogo states:

\footnotetext{
"These are the some of the days of the year when the world looks to the Middle East, gives its opinion and goes back to its previous duties. The war in Gaza flooded my Facebook page and my Twitter account with various reports about the conflict, with opposing positions - and part of them based on misconceptions. One of them is the idea that there is a cohesive Arab world and, on the other side of the mirror, a State of Israel."
} 
A reader replies: "You look Arabic, don't you Mr. Bercito? You would have to be of Arab descent to be so partial, right?" In this case, more than writing to the journalist, the reader expands his comments in an attempt to persuade other interlocutors, pointing to presumably stronger evidence than those triggered in a rational discussion. Following this reasoning, holding the newspaper responsible could implement objective and direct questions, as if pointing fingers at the authors: reacting to the editorials, columns, and reader comments of the July $31^{\text {st }}$ edition of the Folha in 2014 against the Israeli attacks against Gaza which reached civilians of all ages, the reader Helena Kessel (Curitiba/PR) responds with the following post : "Criticizing and pointing fingers at the State of Israel at the expense of the Palestinian victims of the cruel world, as editorials in Folha and some readers and columnists do, is easy and are moving. Now, I ask, what solutions do they present to the resolution of the conflict?" [14]

\section{FINAL CONSIDERATIONS}

The spatial expansion of the voice of public opinion in contemporary times does not correspond only to the range of information and participation made possible by digital culture. It relates, above all, to the multi-platforms on which this process occurs and the implications that it triggers, including keeping up with the dizzying pace of the flow of information and integrating itself to journalism narratives, among others.

Following this context is the possibility of contacting the news in various forms - such as audio, image, audio visual, graphics, documentaries, newsgames ${ }^{[15]}$ - and additional readings that enrich the data in semantic resolution schemes (FIDALGO, 2007) in order to understand the facts, and respond to them also through multiple resources and in distinct registers, the characteristics of which are strongly conditioned to the state of precipitation which the subjects are registered in streams of discussion.

This is the context in which social movement of current informational exchanges assimilated to processes of conversation turned visible and implemented in participatory operations that circulate in the internal structure of the proper media spaces, presenting alternatives between constructions 
of in-depth arguments and other variables ranging from mere accessions or refusals to passionate forms. Far from devaluing its argumentative strength, we must consider that they can take control of interactions, diverting the focus of the topics of discussion to factors articulated to other agendas. These procedures affect the actions of journalists whether it is going back to the agenda and mobilizing resources that give opening, for example, the historical understanding of the facts, or establishing clear demarcations between the spaces of speech, even cleaning and filtering what is considered to be relevant. At any rate, this state of affairs imposes challenges to journalistic organizations as well as to those who seek to address them from a critical point of view.

The new subjectivities established from these spaces of visibility are evident because they go through the traditional information spaces with agility and often trigger action strategies ranging from the data correction notes presented by journalists until the practices deployed by cell phones, restructuring the mediating role of journalism in the scenario of negotiations with governments and powers. It is in this context that the public takes on different forms of participation capable of revealing its fertile energy for determining agendas and strategies and saving its space in media discourse. Looking at it from a different perspective, the headline should be read of an article published on August 1, 2014 ${ }^{[16]}$ concerning the two wars Israel faces, in the front and in the face of international public opinion because it encompasses the concept of public opinion much more than points of view from analyses, journalists and governments included in mediation between the subject and the national and world events. They are in fact voices expressed in stories, analyses, images, comments or music, gestures, actions, coming from different points that cross the media space, creating controversy, questioning positions, trying to put itself in others shoes, and perhaps through private or personal issues, changing what was once first introduced as international news.

*This paper was translated by Lee Sharp 
ANDRADE, Cândido Teobaldo de Souza. Mito e realidade da opinião pública. São Paulo, 1964. Available at: http://rae.fgv.br/rae/vol4-num11-1964/ mito-realidade-opiniao-publica. Accessed on: June 18, 2014.

AUSTIN, John. Quand dire, c'est faire. 4. ed. Paris: Seuil, 1991.

BENVENISTE, Emile. Problemas de linguística geral. 1. ed. São Paulo: Editora Nacional, Editora da Universidade de São Paulo, 1976.

BOGOST, Ian; FERRARI, Simon; SCHEIZER, Bobby. Newsgames: journalism at play. 1. ed. Cambridge, Massachusetts: The MIT Press, 2010.

BORGES, Susana. Opinião pública, Media e Cidadania: as manifestações pela paz nas vésperas da II Guerra do Golfo. In: XXXI CONGRESSO BRASILEIRO DE CIÊNCIAS DA COMUNICAÇÃO - INTERCOM, I COLÓQUIO BRASIL-PORTUGAL DE CIÊNCIAS DA COMUNICAÇÃO, 2008, Natal, RN. Anais do XXXI Congresso Brasileiro de Ciências da Comunicação INTERCOM, I Colóquio Brasil-Portugal de Ciências da Comunicação. Natal: INTERCOM, 2008. V. 1, p. 1 - 12. Available at: http://www2. intercom.org.br/navegacaoDetalhe.php?option=trabalho\&id=35056. Accessed on June 18, 2014.

CHARAUDEAU, Patrick. Discurso das mídias. 1. ed. São Paulo: Contexto, 2006.

DUCROT, O; ANSCOMBRE, L. - CL. L'argumentation dans la langue. 1 . ed. Bruxelles: Mardaga, 1983.

DUCROT, Osvald. Le dire et le dit. 1. ed. Paris: Éditions de Minuit, 1985. O dizer e o dito. 1. ed. Campinas, SP: Pontes, 1987.

FAIRCLOUGH, Norman. Discurso e mudança social. Reimpressão da 1 . ed. Brasília: UnB, 2008.

FIDALGO, António. A resolução semântica no jornalismo online. In: BARBOSA, S. (Org.). Jornalismo digital de terceira geração. Coleção Estudos em Comunicação. Covilhã: Livros Labcom, 2007. [e-book]. p. 93102. Available at:

http://www.livroslabcom.ubi.pt/pdfs/barbosa_suzana_jornalismo_ digital_terceira_geracao.pdf. Accessed on: June 14, 2014. 
HABERMAS, Jürgen. História y critica de la opinión pública. La transformación estructural de la vida pública. 4. ed. Barcelona: Gustavo Gili, Serie Mass Media, 1994.

HAROCHE, Claudine. A condição sensível: formas e maneiras de sentir no Ocidente. Rio de Janeiro: Contra Capa, 2008.

$\mathrm{KOCH}$, Ingedore. A inter-ação pela linguagem. 1. ed. São Paulo: Editora Contexto, 1992.

LANDOWSKI, Eric. A opinião pública e seus porta-vozes. A sociedade refletida: ensaios de sociossemiótica. 1. ed. São Paulo: EDUC/Pontes, 1992.

LATOUR, Bruno. Reagregando o social: uma introdução à teoria do Ator-Rede. 1. ed. Salvador/Bauru: EDUFBA/EDUSC, 2012.

LIPPMANN, Walter. Opinião pública. 2. ed. Petrópolis: Vozes, 2010.

MAGNONI, Antônio Francisco. A comunicação e a opinião pública na era das redes sociais. In: SANTOS, C. M. R.G. dos (Org.). Opinião pública: empowerment e interfaces. 1. ed. Bauru, SP: Universidade Estadual Paulista, Faculdade de Arquitetura, Artes e Comunicação, 2012, p. 38-55.

MAINGUENEAU, Dominique. Análise de textos de comunicação. $4^{\mathrm{a}}$ ed. São Paulo: Cortez, 2005.

MARCUSCHI, Luiz Antonio. Análise da conversação. 5. ed. São Paulo: Ática, 2000.

RECUERO, Raquel. Redes sociais na internet. 1. ed. Porto Alegre: Sulina, 2009.

VIANA, Lucina R. Presença online: estratégias e práticas discursivas da relação intermediada entre coenunciadores no twitter. 2014. Tese (Doutorado em Comunicação e Linguagens) - Faculdade de Ciências Sociais Aplicadas, Universidade Tuiuti do Paraná, Curitiba, 2014.

VICENTE, Maximiliano Martin. Opinião pública e sociedade. In: SANTOS, C. M. R.G. dos (Org.). Opinião pública: empowerment e interfaces. 1. ed. Bauru, SP: Universidade Estadual Paulista, Faculdade de Arquitetura, Artes e Comunicação, 2012, p. 28-36. 


\section{NOTES}

1 A short, preliminary version of this text was presented at the 12 th National Meeting of Research Journalists, SBPJor, UNISC, Santa Cruz do Sul, Nov. 2014. Various reformulations, insertions and specifications were made for it to be published.

2 In this line of mistaken understanding of public opinion lies the material: "than 40 opinion formers in Juiz de Fora", from the Mormon Press, which congregates in a small, select group of sectors, the opinion formers from a society, defined as "public power, private initiative, media, judicial, religious, NGOs, etc." (emphasis added) Available at: http:// www.saladeimprensamormon.org.br/artigo/recepcao-a-formadores-deopiniao-publica-conta-com-mais-de-40-participantes-em-juiz-de-fora.

3 As in the example of Frederico Vasconcelos's blog on Folha online, published on 07/31/2014 with the heading: "Lawyer for Bahia judges awaiting independent action of public opinion from the National Counsel of Justice" (CNJ) Available at: blogdofred.blogfolha.uol.com. br Accessed on 08/02/2014.

4 Available at: http://comentarios 1.folha.com.br/perfil/1056401?skin $=$ folhaonline. Accessed on: 07/31/2014). Criticism of the post on the reader panel on Ricardo Almeida's material, published on 07/28/2014: "Israel is an aberration; not the Jewish" (Available at: http://www1. folha.uol.com.br/colunas/ricardomelo/2014/07/1492075-israel-eaberracao-os-judeus-nao.shtml. Accessed on 07/29/2014).

5 A fictitious campaign and comedic opening at the World Cup in June 2010 which came in first place on the list of Trending Topics on Twitter (most popular issues), with different comedic versions including an institutional-style video created by the group "NERDS KAMIKAZES" and published on YouTube which generated a lot of confusion in international media. The issue highlighted by the hashtag Cala a boca Galvão, was on networks and media agenda. News published on the "New York Times" website titled "A Brazilian Twitter Campaign That Really Is for the Birds" (www.nytimes.com/2010/06/16/nyregion/16about.html? $r=0$ ), on $06 / 15 / 2010$ illustrates the misinterpretation of the issue and the repercussions of the fact.

6 Cf., for example, one of the comments about Diogo Bercito's post from the blog called Orientalissimo, available at: http://orientalissimo. blogfolha.uol.com.br/2014/08/01/israel-e-os-estados-arabescontra-o-hamas/ "Who does the land of Israel and its surroundings 
belong to (called Palestine)? The State of Israel has existed since the time of King David and there has never been a Palestine state there. I'm not against the palestinians having their territory; but to say Israel is the invador is distorting the truth. If they spoke the truth, maybe they achieve peace, if not, only wars!"

7 Available at: http://blogs.odia.ig.com.br/amoresurbanos/2014/08 /15/de-que-lado-voce-esta-palestina-ou-israel/. Accessed on: 08/16/2014.

8 Naming sources of problems or issues when approaching a topic becomes common in online journalism and gives the impression of total dominion over a complex fact. One such example: "10 questions to help understand the conflict between Israelis and Palestinians". (Available at: http://www.bbc.com/portuguese/noticias/2014/08/140730_gaza _entenda_gf_lk. Accessed on: 09/29/2014.)

9 Cf., for example, lone Aguiar's material in the Brasil Post titled "Palestinian teenager tells of her daily life in the Gaza Strip on her Twitter account" Available at: http://www.brasilpost.com. br/2014/08/11/gaza-twitter-adolescente_n_5669878.html. Accessed on: 08/12/2014.

10 See the exchange of comments on the material "Israel and Palestinians agree to new cease fire", on the UOL website describing that argumentative participation overlaps from interventions from the following different authors' discourses: "Only if they go home, because Israel invaded and occupied or blocked their territories!!!"/ "How is Santa Claus doing ???????????" "hahaha, don't talk so silly you liar". Available at: http://noticias.uol.com.br/internacional/ultimasnoticias/2014/08/10/israel-e-palestinos-aceitam-novo-cessar-fogoem-gaza-dizem-fontes.htm\#comentarios. Accessed on: 08/11/2014.

11 Lucina Reitenbach Viana's doctoral thesis defended on 03/27/2014 analyzes forms of interacction present in the blog of journalist Rosana Hermann, examining exemplary cases of strategies understood by Hermann as keeping control of interaction on a topic. (Doctoral thesis/ PPG in Communication and Languages/UTP).

12 It is interesting to see comments about a possible solution to the Israel-Palestine conflict in the Gaza Strip, whether following the rational arguments presented in a material or divert attention of a topic to absurd proposals or strong content. One example is observed in the comments following the material at: http://www1.folha.uol. com.br/mundo/2014/07/1494066-israel-e-hamas-aceitam-cessarfogo-humanitario-incondicional-de-72-horas.shtml. 
13 Avavilable at: http://orientalissimo.blogfolha.uol.com.br/2014/08 /01/israel-e-os-estados-arabes-contra-o-hamas/. Accessed on: 08/02/2014.

14 Available at: http://www1.folha.uol.com.br/paineldoleitor/2014/ 07/1493080-leitores-comentam-artigos-sobre-conflito-entre-israel-epalestina.shtml. Accessed on: 08/01/2014.

15 Ian Bogost refers to the spatial value given to the experience of a fact in newsgames, as well as historic coordenates that are built on in the same interaction by the game. Newsgames corresponds to the way journalism is made for electronic games, with the idea that each one is placing itself in the place of the other. The author's work newsgame Peacemaker, which also refers to the Israel-Palestine conflict already mentioned here, illustrates her objective to support reasonable opinions and look for possible negotiations to avoid war.

16 WOLOSZYN, André Luís. Israel in the middle of two wars: on the front and in international public opinion. www.defesanet.com.br, $07 / 31 / 2014$.

Kati Caetano is a professor of the Graduate
Program in Communication and Languages
(Master's degree and PhD) at the University Tuiuti
do Paraná. Member of the Line of Research “
Mediatic Processes and Interactional Practices"
of the PPGCOM / UTP and leader of the Research
Group "Communicational Interactions, Images
and Digital Cultures" - INCOM / UTP/CNPq.
Author of articles and scientific papers on the
relationship between communication, images
and technologies paying a particular attention
to the space-time expansion processes in the
digital technologies in the field of journalistic
information and urban practices.

RECEIVED ON: 23/02/2015 | APPROVED ON: 26/04/2015 